\title{
Synthesis of High Molecular Weight Polyphosphate with a Partially Purified Enzyme from Salmonella
}

\author{
By P. F. MÜHLRADT \\ Max-Planck-Institut für Immunbiologie, \\ Freiburg-im-Breisgau, Germany \\ (Accepted for publication 3 July $197 \mathrm{r}$ )
}

\begin{abstract}
SUMMARY
Polyphosphate (polyP) kinase was prepared from EDTA-lysozyme spheroplasts of a Salmonella minnesota rough mutant. The enzyme, purified about $80-$ fold, was free of ATPase and polyP-degrading activity and contained neither nucleic acids nor polyP which might act as primer. Using this enzyme, ${ }^{32} \mathrm{P}$-labelled polyP was prepared from $\left.{ }_{\gamma}^{32} \mathrm{P}\right] \mathrm{ATP}$. The polyP was identified by the action of degrading enzymes, phenol extraction, adsorption characteristics on charcoal and hydrolysis kinetics.

Sedimentation data in sucrose gradients $(S=I I \cdot 5)$ and gel filtration on agarose indicated a molecular weight in the range 300,000 to 400,000 daltons.
\end{abstract}

\section{INTRODUCTION}

Enzymes synthesizing polyP have been detected in many biological systems ranging from bacteria to mammalian cell nuclei (for extensive reviews see Kuhl, I960; Harold, 1966), but to our knowledge only two bacterial enzymes have been extensively purified, one from Escherichia coli (Kornberg, Kornberg \& Simms, 1956), and the other from Corynebacterium xerosis (Muhammed, 196I).

Several reports have mentioned the high molecular weight of the polyP encountered in bacteria (Kornberg et al. 1956), yeast (Liss \& Langen, I960), slime moulds (Sauer, Babcock \& Rusch, 1969), moulds (Ingelman \& Malmgren, 1950), and blue-green algae (Correll, 1964). However, most isolation procedures (except those of Sauer et al. (1969) and of Ingelman \& Malmgren (1950)) involve extraction steps with TCA or $\mathrm{NaOH}$ which will certainly degrade long-chain polyP to an extent that would make any estimate of the molecular weight unreliable. A better method of obtaining undegraded polyP is therefore by enzymatic synthesis using a purified enzyme.

During our studies on the biosynthesis of cell-wall constituents of Salmonella bacteria (Mühlradt, 197I) we encountered in protein extracts of these bacteria enzyme-catalysed transfer of phosphate from ATP to a substance which we have named X-P. This communication reports that X-P is polyphosphate of very high molecular weight.

\section{METHODS}

Reagents. The following reagents and enzymes were purchased from C. F. Boehringer \& Söhne (Mannheim, Germany): ATP, ADP, phosphoenolpyruvate, NADH, pyruvate kinase (EC 2.7 . I .40), lactate dehydrogenase (EC I I . I . 27) from pig heart, egg-white lysozyme (EC 3.2.I . I 7), RNase from pancrease, trypsin (EC 3 4.4.4) from pancreas, and inorganic pyrophosphatase (EC 3.6.r.I) from yeast. DNase was purchased from Serva Entwick- 
lungslabor (Heidelberg, Germany); Escherichia coli type III alkaline phosphatase (EC 3. I.3. I) was obtained from Sigma Chemicals Co. (St Louis, Missouri, U.S.A.). ${ }_{\gamma}^{32}$ P]ATP was prepared according to Glynn \& Chappel (I964). The tRNA and ribosomal RNA used in the sucrose gradients as internal markers were prepared from EDTA-lysozyme spheroplasts which were lysed with $\mathrm{Na}$ dodecylsulphate (SDS). The preparation was extracted with phenol at room temperature, and the RNA was precipitated with ethanol from the aqueous phase.

Paper electrophoresis and autoradiography. High-voltage paper electrophoresis was carried out at $60 \mathrm{~V} / \mathrm{cm}$. in a buffer of pyridine + acetic acid + water (ro:4:86, by vol.), pH 5.5. Radioactive zones were located on ADOX Doneo X-ray film, clear base.

Disc electrophoresis. Acrylamide-gel disc electrophoresis was carried out by the procedure of Davis (1964). No sample gel was used, but the samples were mixed with a small amount of glycerol and applied directly to the small pore gel. The electrophoresis was performed in the cold room and for efficient cooling of the electrophoresis tubes cold air was blown through the apparatus.

For determination of radioactive zones the gel was carefully removed from the tubes and cut in small sections. The sections were dissolved in the following scintillation fluid which was used throughout the experiments reported here: toluene-triton X-IOo $(2: \mathrm{I}, \mathrm{v} / \mathrm{v})$ containing $4 \%$ 'Omnifluor' ( $98 \%$ 2,5-diphenyl-oxazole plus $2 \%$ bis $(O$-methyl-steryl)benzene). Radioactivity was determined in a Packard liquid scintillation spectrometer.

Protein estimations. Protein was determined by the method of Lowry, Rosebrough, Farr \& Randall (195I), bovine serum albumin (BSA) serving as standard.

Sucrose gradient centrifugation. Sucrose gradient centrifugation was performed in a Beckman Spinco model L 2-65 B ultracentrifuge. PolyP samples (I00 $\mu 1$.) containing about 5 n-equiv. of $\mathrm{Pi}$ (20,000 c.p.m.), with tRNA and ribosomal RNA from Salmonella as internal markers, were layered on top of a 30 to $8 \%(\mathrm{w} / \mathrm{w})$ sucrose gradient in standard citrate buffered saline $\left(0^{\circ} \mathrm{I}_{5} \mathrm{M}-\mathrm{NaCl}+0^{\circ} \mathrm{OI} 5 \mathrm{M}\right.$-citrate, $\left.\mathrm{pH} 7^{\circ} \mathrm{O}\right)$. Usually, $4 \mathrm{~h}$. runs were carried out at $5^{\circ}$ and $50,000 \mathrm{rev} . / \mathrm{min}$. (280,000 $\mathrm{g}$ average) in a SW 56 rotor. The polyallomer tubes were punctured at the bottom and samples corresponding to $2 \mathrm{~mm}$. segments were withdrawn. The samples were diluted with tris buffer, $\mathrm{pH} 7 \cdot 0$, and the extinction at $260 \mathrm{~nm}$. measured. Either the whole fractions or portions thereof were then assayed in a scintillation counter.

Organisms and culture. Salmonella minnesota $\mathrm{mR} 5$ is a rough mutant with a defective heptose phosphorylating enzyme (Mühlradt, I969); it was isolated by J. Schlosshardt (Zentrallaboratorium für bakterielle Darminfektionen, Berlin-Pankow, D.D.R.). Cultures were grown in I 1 . batches in Difco antibiotic medium 3 and harvested in the late exponential growth phase. The organisms were washed twice with $0.0 \mathrm{I}$ M-tris-chloride buffer, $\mathrm{pH} 8 \cdot 0$, and kept at $-20^{\circ}$.

Preparation of enzyme. Protein extracts were prepared by repeated washing of EDTA lysozyme spheroplasts with 0.0 I M-tris- $\mathrm{Cl}, \mathrm{pH} \mathrm{8.0,} \mathrm{as} \mathrm{previously} \mathrm{described} \mathrm{(Mühlradt,} \mathrm{I969).}$ The extracts (usually from 5 to $6 \mathrm{~g}$. wet wt bacteria) were centrifuged at $150,000 \mathrm{~g}$ for $3 \mathrm{~h}$. The enzyme was exclusively in the sediment which was suspended in a few ml. O.I M-trissulphate buffer, $\mathrm{pH} 8 \cdot 0$, I mM-EDTA, $0.5 \mathrm{mM}$-2-mercaptoethanol buffer.

RNase, ammonium sulphate extraction step: after addition of $30 \mu \mathrm{g}$. RNase $/ \mathrm{ml}$. the suspension was incubated at $25^{\circ}$ for $20 \mathrm{~min}$. The polyP kinase activity sedimented now at $1000 \mathrm{~g}$ in $10 \mathrm{~min}$. The sediment was twice extracted at $25^{\circ}$ with $2 \mathrm{ml} .0 .02 \mathrm{M}$-tris-sulphate, pH 8.0, 0.2 M-( $\left(\mathrm{NH}_{4}\right)_{2} \mathrm{SO}_{4}$, I mM-EDTA, 0.5 mM-2-mercaptoethanol buffer. The polyP kinase activity was in the extract. 
Ammonium sulphate step: the extract was made $2 \mathrm{M}$ in $\left(\mathrm{NH}_{4}\right)_{2} \mathrm{SO}_{4}$ and the protein precipitate containing the polyP kinase was obtained upon centrifugation. The sediment was dissolved in a minimum of $0.02 \mathrm{M}$-tris-sulphate, $\mathrm{pH} 8.0,0.2 \mathrm{M}-\left(\mathrm{NH}_{4}\right)_{2} \mathrm{SO}_{4}$, I mM-EDTA, $0.5 \mathrm{~mm}$ 2-mercaptoethanol buffer.

DEAE-cellulose step: the fraction from the ammonium sulphate step was diluted to $0.05 \mathrm{M}$ $\left(\mathrm{NH}_{4}\right)_{2} \mathrm{SO}_{4}$ with 0 -or M-tris-sulphate buffer, $\mathrm{pH} 8 \cdot 0$, and immediately applied to a DEAEcellulose column containing $10 \mathrm{ml}$. resin. The column was eluted with a 0 to $0.32 \mathrm{M}-$ $\left(\mathrm{NH}_{4}\right)_{2} \mathrm{SO}_{4}$ gradient in $0.01 \mathrm{M}$-tris-sulphate buffer, $\mathrm{pH} 8 \cdot 0$. PolyP kinase was eluted in one peak at $0 . \mathrm{I}_{5} \mathrm{M}-\left(\mathrm{NH}_{4}\right)_{2} \mathrm{SO}_{4}$. The active fractions were pooled and concentrated on a Sartorius protein filter no. I 5100.

Enzyme assay. Precipitation test (Kornberg, 1956): the incubation mixture (250 $\mu 1$.) was O.I M-tris-sulphate buffer, $\left.\mathrm{pH} 8.0 ; 0 . \mathrm{I} \mathrm{M}^{\mathrm{M}}\left(\mathrm{NH}_{4}\right)_{2} \mathrm{SO}_{4} ; 0.04 \mathrm{M}-\mathrm{MgSO}_{4} ; 0.0 \mathrm{I} \mathrm{M}-{ }_{\gamma}^{32} \mathrm{P}\right]-\mathrm{ATP}$, specific activity 1000 to 10,000 c.p.m./nmole, and it contained $0 . \mathrm{I}$ to $\mathrm{I} \times 1 \mathrm{IO}^{-3}$ units polyP kinase.

After $30 \mathrm{~min}$. incubation at $25^{\circ}, 40 \mu 1$. I.5\% BSA solution containing $2.5 \mu \mathrm{g}$. $/ \mathrm{ml}$. RNA was added as carrier, and the polyP was precipitated with $250 \mu 1$. I $5 \%$ trichloroacetic acid (TCA) in $\mathrm{O} \cdot \mathrm{I} \mathrm{M}-\mathrm{KH}_{2} \mathrm{PO}_{4}$ and centrifuged. The precipitate was dissolved in $0 . \mathrm{I}_{2}^{\mathrm{N}} \mathrm{N}-\mathrm{NaOH}$ and reprecipitated with TCA solution. The precipitate was washed again with $250 \mu \mathrm{l}$. TCA solution and was finally dissolved in $100 \mu \mathrm{l} .100 \% \mathrm{HCOOH}$. Its radioactivity was counted in a scintillation spectrometer. Control mixtures without enzyme contained about $0.3 \mathrm{nmole}$ [22 P]phosphate. An enzyme unit is defined as the amount of enzyme which incorporates I $\mu$ mole of TCA-precipitable $\left[{ }^{32} \mathrm{P}\right]$ phosphate/min. under the above conditions.

Spectrophotometric assay: the incubation mixture $(300 \mu \mathrm{l}$.) contained $0 \cdot \mathrm{I}$ M-tris-sulphate buffer, pH 8.0; O.I M-( $\left(\mathrm{NH}_{4}\right)_{2} \mathrm{SO}_{4} ; 0.04 \mathrm{M}-\mathrm{MgSO}_{4} ; 0.0 \mathrm{I} \mathrm{M-ATP;0.33} \mathrm{mM-phosphoenol-}$ pyruvate; $0.33 \mathrm{~mm}-\mathrm{NADH}$, with $8 \mu \mathrm{g}$. lactate dehydrogenase, $3.5 \mu \mathrm{g}$. pyruvate kinase, and about $10^{-3}$ units of polyP kinase. The decrease in extinction at $340 \mathrm{~nm}$. was followed for $30 \mathrm{~min}$. at $25^{\circ}$. The reaction rate remained linear with time for more than $30 \mathrm{~min}$.

Preparation of ${ }^{32} P$-labelled polyP. A sample $(0.75 \mathrm{ml}$.) of the assay mixture described above was incubated for $45 \mathrm{~min}$. at $25^{\circ}$. The mixture was filtered through a $0.9 \times 22 \mathrm{~cm}$. Sephadex G-75 column with $0.0 \mathrm{I}$ M-tris buffer, $\mathrm{pH} 8 \cdot 0$, as eluant. PolyP was eluted in the exclusion volume and was thus separated from the remaining ATP.

\section{RESULTS}

Purification of the enzyme. The crude protein-containing extract was prepared by repeated washing of cells which had been partially lysed by EDTA and lysozyme (Mühlradt, I959). This procedure was more time-consuming than ultrasonication, but yielded a preparation of higher specific activity. The further purification of the enzyme was somewhat similar to the procedure of Kornberg et al. (1956) except that the last step employed chromatography on DEAE-cellulose. When the RNase step was omitted, a second peak of polyP kinase activity in addition to the one eluted at $0.15 \mathrm{M}-\left(\mathrm{NH}_{4}\right)_{2} \mathrm{SO}_{4}$ was eluted at $0.3 \mathrm{M}$-salt. RNase treatment resulted in the loss of this second peak of activity and a concomitant increase of activity in the first peak. The purification steps are outlined in Table I. The polyP kinase obtained after the DEAE-cellulose chromatography contained neither polyP nor nucleic acids. These substances were eluted from the column at considerably higher salt concentrations than the enzyme. Activity determinations on this enzyme preparation using the precipitation test and the spectrophotometric assay under identical conditions - i.e. under ATPregenerating conditions - gave the same results. Any ATPase activity would have resulted 
in seemingly higher activities in the spectrophotometric assay. No polyPase activity could be detected in this enzyme preparation.

Properties of the enzyme. The Salmonella polyP kinase appeared to be very similar to the Escherichia coli enzyme described by Kornberg (1956). It was soluble when nucleic acid was present and sedimented only upon ultracentrifugation for $3 \mathrm{~h}$. at $150,000 \mathrm{~g}$. After

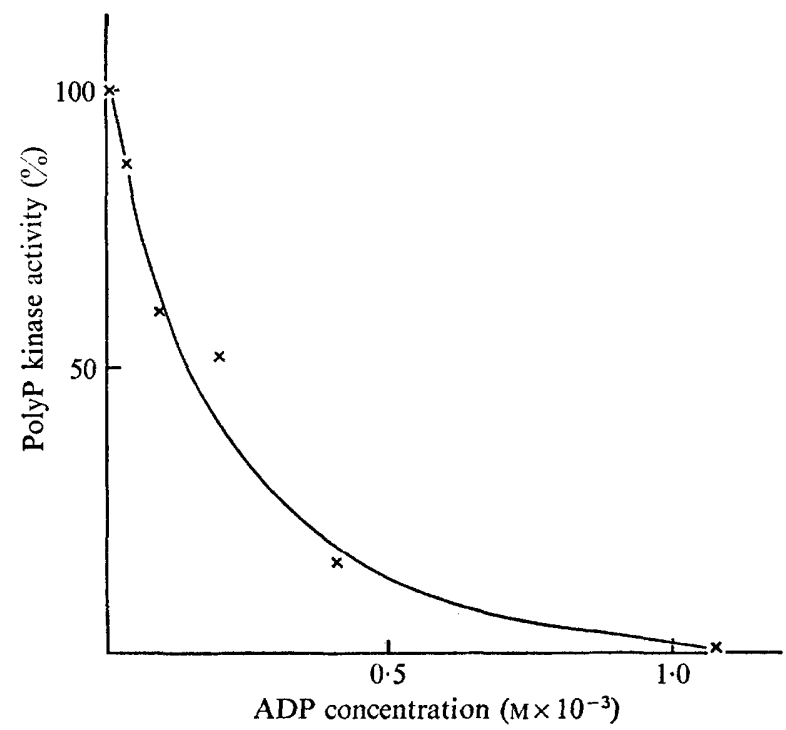

Fig. I. ADP-inhibition of polyP kinase activity. Incubation mixture ( $250 \mu \mathrm{l}$.) contained: I00 mM-

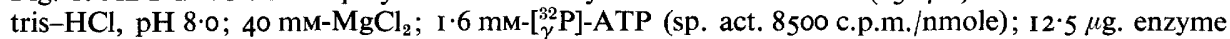
protein, and ADP as indicated. Incubation time: $30 \mathrm{~min}$. at $25^{\circ}$.

\section{Table I. Purification procedure of polyP kinase}

\begin{tabular}{|c|c|c|c|c|c|c|}
\hline Preparation & $\begin{array}{l}\text { Volume } \\
\text { (ml.) }\end{array}$ & $\begin{array}{l}\text { Protein } \\
(\mathrm{mg} . / \mathrm{ml} .)\end{array}$ & $\begin{array}{c}\text { Activity } \\
\text { (units/ml. } \\
\times I 000 \text { ) }\end{array}$ & $\begin{array}{l}\text { Spec. } \\
\text { activity } \\
\text { (units } / \mathrm{mg} \text {. } \\
\text { protein } \\
\times 1000 \text { ) }\end{array}$ & $\begin{array}{l}\text { Yield } \\
(\%)\end{array}$ & $\begin{array}{l}\text { Purification } \\
\text { (-fold) }\end{array}$ \\
\hline EDTA-lysozyme lysate & 50 & 0.8 & 0 & 0 & - & - \\
\hline Tris-extract & 100 & $0 \cdot 8$ & 0.47 & 0.6 & 100 & I \\
\hline I 50,000 $g$ Sediment & 4 & $5 \cdot 2$ & $10 \cdot 0$ & $1 \cdot 93$ & 86 & 3 \\
\hline $\begin{array}{l}(\mathrm{NH})_{4} \mathrm{SO}_{4}-\text { extraction } \\
\text { after RNase treatment }\end{array}$ & $2 \cdot 8$ & $3 \cdot 2$ & $19 \cdot 0$ & 5.94 & I I4 & IO \\
\hline $\begin{array}{l}(\mathrm{NH})_{4} \mathrm{SO}_{4} \text { - fractiona- } \\
\text { tion }\end{array}$ & 4 & 0.4 & $6 \cdot 1$ & $15 \cdot 2$ & $5 \mathrm{I}$ & 25 \\
\hline $\begin{array}{l}\text { DEAE-cellulose eluate } \\
\text { after concentration }\end{array}$ & $\mathrm{I} \cdot 7$ & 0.08 & $3 \cdot 7$ & $46 \cdot 6$ & 14 & 78 \\
\hline
\end{tabular}

RNase treatment, which rendered the polyP kinase insoluble, the enzyme could be redissolved in $0.2 \mathrm{M}$-ammonium sulphate. The enzyme is activated by potassium and ammonium sulphate, but not by ammonium chloride. Both Escherichia coli and Salmonella polyP kinases were inhibited by ADP (Fig. I). The $K_{\mathrm{m}}$ value for ATP determined by the spectrophotometric assay was $(\mathrm{I} \cdot 25 \pm 0 \cdot \mathrm{I}) \times 1 \mathrm{IO}^{-3} \mathrm{M}$.

Identification of the reaction product as polyphosphate. Prior to identification, the reaction product formed on incubation of ATP with extract was named X-P. The high molecular 
nature of X-P soon became apparent because it could be co-precipitated with BSA and separated from ATP by gel filtration on Sephadex G200.

Action of degrading enzymes on $X-P$. Samples of X-P prepared enzymatically, containing 0.5 n-equiv. phosphate (5000 c.p.m.), were incubated with deoxyribonuclease, ribonuclease, inorganic pyrophosphatase, trypsin or alkaline phosphatase at $30^{\circ}$ for $5 \mathrm{~min}$., while a control sample was incubated in $0.05 \mathrm{M}$-tris buffer, $\mathrm{pH}$ 7.5. Sucrose gradient centrifugation and paper electrophoresis indicated some degradation with alkaline phosphatase but none with trypsin, like the control. Pyrophosphatase degraded the X-P to yield products too small to sediment in the sucrose gradient but of too high molecular weight to migrate in the electrophorogram. Deoxyribonuclease and ribonuclease had the strange effect of increasing the adsorption of the radioactive material to the glass test tubes. However, no degradation was noted.

Phenol extraction, adsorption on charcoal. A sample of X-P containing 57 n-equiv. of phosphate $(250,000$ c.p.m.) in $250 \mu \mathrm{l}$., I mM-EDTA, $0.0 \mathrm{I}$ tris buffer, $\mathrm{pH} 8.0$, containing I \% SDS, was extracted three times with an equal volume of buffer-saturated phenol at $5^{\circ}$. All of the radioactivity remained in the aqueous phase. The material was undegraded according to sucrose gradient centrifugation and gel filtration on Sephadex $4 \mathrm{~B}$.

Muller-Felter \& Ebel (1962) separated polyP and nucleic acids by selective adsorption on charcoal which, with $0.5 \mathrm{M}-\mathrm{NaCl}$, selectively adsorbs high molecular weight substances such as proteins, lipids, polysaccharides, nucleic acids but not polyP. X-P containing $50 \mathrm{n}-$ equiv. phosphate (200,000 c.p.m.) was therefore mixed with $125 \mu \mathrm{g}$. yeast RNA and $55 \mu \mathrm{g}$. commercial polyP (degree of polymerization about 8 ) as carrier, made up to $0.5 \mathrm{ml}$. in $0.5 \mathrm{M}-\mathrm{NaCl}$ and shaken with $\mathrm{I} 0 \mathrm{mg}$. charcoal for $5 \mathrm{~min}$. at room temperature. The charcoal was removed by centrifugation and the supernatant solution was assayed for radioactivity and for nucleic acid. Ninety-eight $\%$ of the nucleic acid had been adsorbed but $84 \%$ of X-P was still present in the supernatant. Again no degradation of X-P had taken place.

Kinetics of hydrolysis in $\mathrm{O} \cdot \mathrm{I} \mathrm{N}-\mathrm{HCl}$ at $60^{\circ}$. X-P containing 90 n-equiv. of phosphate (200,000 c.p.m.) was hydrolysed in $3 \mathrm{ml}$. $0 . \mathrm{I} \mathrm{N}-\mathrm{HCl}$ at $60^{\circ}$. Samples $(250 \mu \mathrm{l}$.) were withdrawn at various times and immediately frozen at $-80^{\circ}$. Residual undegraded X-P was assayed by (a) precipitation with $7 \%$ TCA after addition of $500 \mu \mathrm{g}$. of BSA/sample as carrier, $(b)$ as the fraction which did not migrate upon paper electrophoresis. Both assay methods gave first-order kinetics of hydrolysis with half-times of 9 and $37 \mathrm{~min}$. respectively. This difference in half-time is easily explained, since assay (a) measured material of much higher molecular weight than did assay (b). Thilo (I959) reported a half-time of $23 \mathrm{~min}$. for acid hydrolysis of polyP under comparable conditions. Paper electrophoresis of partially hydrolysed X-P revealed a number of spots migrating both faster and slower than inorganic phosphate. They represented polyP fractions of different chain lengths. On total hydrolysis these spots disappeared, yielding a single zone of inorganic phosphate as the product. The above results indicate that X-P is a polyP of high molecular weight.

Sedimentation data. Because enzymatic preparation of sufficient material for analysis in the analytical ultracentrifuge was not feasible, the sedimentation coefficient had to be determined from sedimentation data using radioactive polyP in a sucrose gradient (Fig. 2). In this experiment ribosomal RNA and tRNA from Salmonella served as internal markers. The sedimentation properties of the polyP did not change after phenol extraction and the polyP was prepared using enzyme fractionated on DEAE-cellulose.

Occasionally, when rather crude enzyme had been used to prepare the polyP sample, a faster sedimenting peak was observed in addition to that shown in Fig. 2. This material 


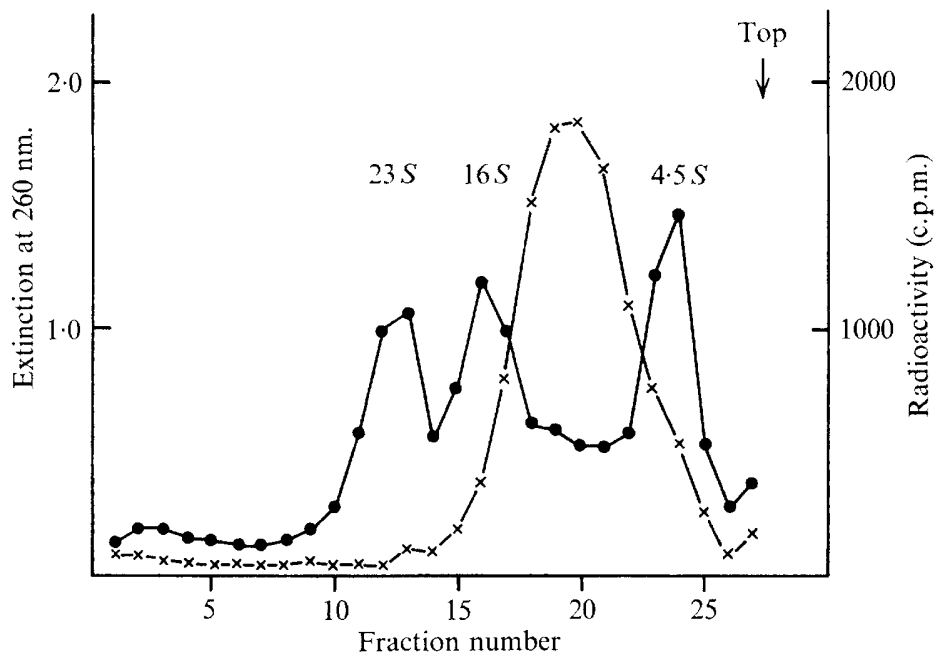

Fig. 2. Sucrose gradient centrifugation of polyP. A Ioo $\mu$ l. sample containing 2 n-equiv. $\left[{ }^{32} \mathrm{P}\right]$ polyP (sp. act. 6500 c.p.m./n-equiv. Pi), with tRNA and ribosomal RNA from Salmonella as markers, was layered on top of a 30 to $8 \%(\mathrm{w} / \mathrm{w})$ sucrose gradient in $0.15 \mathrm{M}-\mathrm{NaCl}, 0.015 \mathrm{M}$-sodium citrate, $\mathrm{pH} 77^{\circ}$. Centrifugation was performed in a Spinco SW 56 rotor at $280,000 \mathrm{~g}$ (average) for $4 \mathrm{~h}$. at $5^{\circ}$. The tube was punctured at its base and fractions corresponding to $2 \mathrm{~mm}$. segments were withdrawn. $x-x-x$, Counts $\times$ min. $^{-1} ;-0$, extinction at $260 \mathrm{~nm}$.

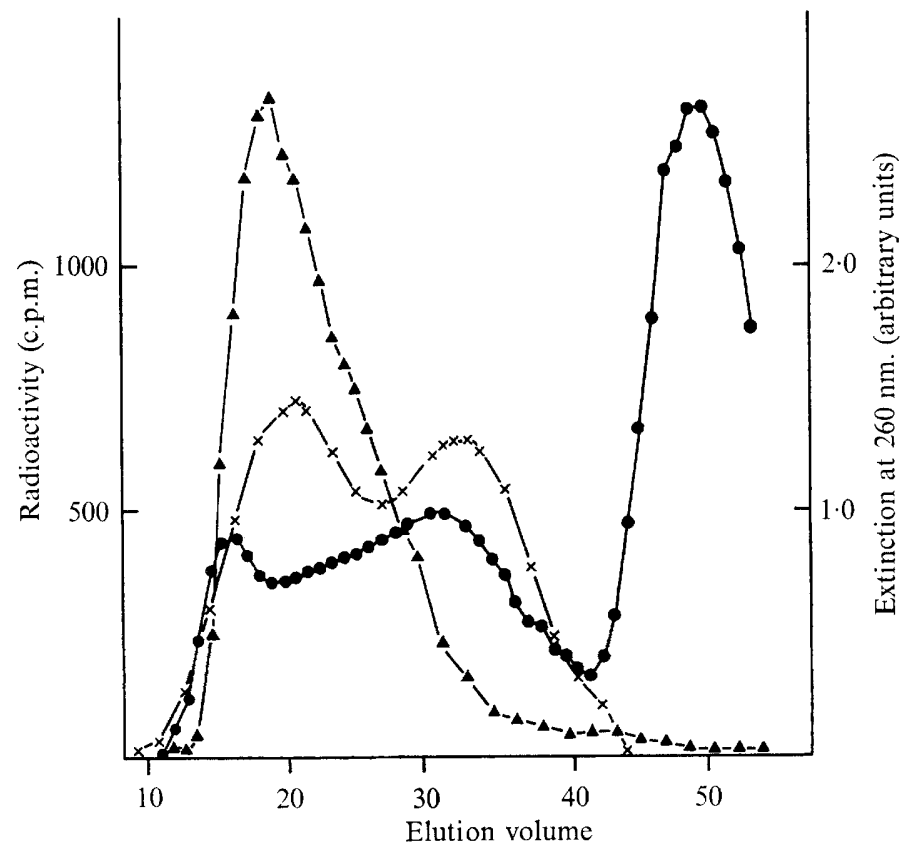

Fig. 3. Gel filtration of polyP on Sepharose 4 B. A $350 \mu$ l. sample containing I4 n-equiv. phenol extracted polyP (sp. act. 4 I00 c.p.m./n-equiv. Pi), with tRNA and ribosomal RNA from Salmonella as markers, was filtered through a $\mathrm{I} \cdot 4 \times 35 \mathrm{~cm}$. Sepharose $4 \mathrm{~B}$ column. Elution buffer: Io mM-tris$\mathrm{HCl}, \mathrm{pH} 7.0 ; \mathrm{I}$ mM-EDTA; $0 . \mathrm{I} \%$ SDS. Elution rate: $0.9 \mathrm{ml}$./h. Elution was carried out at $5^{\circ}$. $\Delta-\Delta-\Delta$, Counts $\times$ min..$^{-1} ; x-x-x$, extinction at $260 \mathrm{~nm}$. (RNA); -0 , extinction at $260 \mathrm{~nm}$. (blue dextran and adenosine). 
disappeared upon phenol extraction, and was possibly an aggregate of the more slowly sedimenting material.

The integrating tables of McEwen (1967), which only apply to particle densities up to $\mathrm{I} \cdot 9$, indicated an $S_{\mathrm{W}, 20}$ value of II $5 \pm 15 \%$ for the peak fraction in three different experiments. The actual $S_{\mathrm{W}, 20}$ value must be somewhat lower because polyP has a particle density of $3 \cdot 2$ (Malmgren, 1952), but the influence of the particle density is not very great in these calculations.

Gel filtration on agarose. A sample of polyP prepared using DEAE-treated enzyme free of degrading activities, was extracted with phenol at $0^{\circ}$ and filtered through an agarose gel (sepharose $4 \mathrm{~B}$ ) in $0.01 \mathrm{M}$-tris buffer, $\mathrm{pH} 8.0$, containing I mM-EDTA, plus $0 . \mathrm{I} \%$ SDS to prevent aggregation. Salmonella ribosomal RNA and tRNA were reference substances (Fig. 3). PolyP was eluted as a broad, asymmetrical peak somewhat earlier than I $6 S$ and $23 S$ RNA. As already reported by Öberg \& Philipson (1967), I6 $S$ and $23 S$ RNA were eluted in one peak.

Disc electrophoresis on acrylamide gel. A sample of polyP was subjected to disc electrophoresis on $5 \%$ acrylamide gel in a glycine buffer of $\mathrm{pH} 8.3$ containing I mM-EDTA and I \% SDS. The substance did not penetrate the gel. The experiment had to be performed at low temperature because otherwise some degradation of the polyP took place during the electrophoresis.

\section{DISCUSSION}

Long-chain linear polyP was extremely labile. It was broken down even if enzymatic degradation was prevented by the use of a purified polyP kinase for its preparation and when it was isolated under very mild conditions. For instance, mere treatment of polyP at $\mathrm{pH} 8.3$ and $40^{\circ}$ for only I $\mathrm{h}$. caused some cleavage, as became evident in our first attempts to subject it to disc electrophoresis. Only when the temperature was lowered to $5^{\circ}$ was this breakdown negligible.

PolyP kinase synthesized polyP of considerable chain length. The appearance of a small fraction of lower molecular weight polyP in the gel filtration experiment was probably due to its instability.

PolyP was eluted earlier from agarose gel than were the ribosomal RNAs, yet it sedimented slower than these substances in the sucrose gradients. These findings are seemingly contradictory. Although nothing is known of the shape of the polyP molecule in solution, nor of its tendency to form aggregates, one might reasonably assume that aqueous polyP behaves similarly to denatured, single-stranded nucleic acid since both compounds are long-chain polyanions. If this assumption is correct, our gel filtration and sedimentation data become consistent, because a given length of linear polyP is only about one-third as heavy as single-stranded nucleic acid of comparable chain length (computed from values given for $\phi \times$ I 74 phage DNA by Freifelder, Kleinschmidt \& Sinsheimer (1964) and for polyphosphate by Thilo (1959).

Malmgren (I952) has shown a pronounced dependence of the sedimentation values of chemically synthesized polyP on polyP concentration as well as on the composition of the solvent. He reported an $S_{0}$ value of 14 for a polyP of 480,000 mol. wt when sedimented in O. I M-NaCl. Our enzymatically prepared polyP had at negligible concentrations an $S$ value of $\mathrm{II}_{\mathrm{I}} \mathrm{5}$ in $0 . \mathrm{I}_{5} \mathrm{M}-\mathrm{NaCl}$ and would thus have a molecular weight in the range of 300,000 to 400,000 .

Several authors have suggested that RNA-polyP complexes exist (Correll, 1964; Wang \& Mancini, 1966). We found no evidence for such a complex in our system. The polyP kinase 
from Salmonella required neither RNA nor a polyP primer for activity, though the enzyme was associated with RNA, as was evident from its altered solubility and changed behaviour on DEAE-cellulose after RNase treatment. This, and the fact that it could be solubilized by a mild procedure known to release enzymes from membranes (Munoz, Nachbar, Schor \& Salton, I968; Mühlradt, I969) suggests that the polyP kinase in its natural state is bound to the cytoplasmic membrane.

This work was supported in part by the Deutsche Forschungsgemeinschaft, Sonderforschungsbereich 46. I thank Miss C. Widemann for excellent technical assistance.

\section{REFERENCES}

Correll, D. L. (1964). Ribonucleic acid-polyphosphate from algae. II. Physical and chemical properties of the isolated complexes. Plant and Cell Physiology 5, I7I-I9I.

Davis, B. J. (1964). Disc electrophoresis. II. Method and application to human serum proteins. Annals of the New York Academy of Sciences 121, 404-427.

Freifelder, D., Kleinschmidt, A. K. \& SinSheimer, R. L. (1964). Electron microscopy of single-stranded DNA: circularity of DNA of bacteriophage $\phi \times 174$. Science, New York 146, 254-255.

GlynN, I. M. \& Chappel, J. B. (1964). A simple method for the preparation of ${ }^{32}$ P-labelled adenosine triphosphate of high specific activity. Biochemical Journal 9o, 147-149.

Harold, F. M. (I966). Inorganic polyphosphates in biology: structure, metabolism and function. Bacteriological Reviews 30, 772-794.

INGELMAN, B. \& MALMGREN, H. (1950). Investigations on metaphosphates of high molecular weight isolated from Aspergillus niger. Acta chemica scandinavica 4, 478-486.

Kornberg, A., Kornberg, S. R. \& Simms, E. S. (I956). Metaphosphate synthesis by an enzyme from Escherichia coli. Biochimica et biophysica acta 20, 215-227.

Kunt, A. (1960). Die Biologie der kondensierten anorganischen Phosphate. Ergebnisse der Biologie 23, I44-I 86.

Liss, E. \& Langen, P. (1960). Uber ein hochmolekulares Polyphosphat der Hefe. Biochemische Zeitschrift 333, 193-20I.

Lowry, O. H., Rosebrough, N. J., Farr, A. L. \& Randall, R. J. (I95I). Protein measurement with the Folin phenol reagent. Journal of Biological Chemistry 193, 265-275.

MaLmGren, H. (1952). A contribution to the physical chemistry of colloid metaphosphates. II. Acta chemica scandinavica $6, \mathrm{I}-\mathrm{I} 5$.

McEwen, C. R. (1967). Tables for estimating sedimentation through linear concentration gradients of sucrose solution. Analytical Biochemistry 20, I 14-I49.

Munammed, A. (196I). Studies on biosynthesis of polymetaphosphate by an enzyme from Corynebacterium xerosis. Biochimica et biophysica acta 54, $12 \mathrm{I}-132$.

MüHLRADT, P. F. (1969). Biosynthesis of Salmonella lipopolysaccharide. The in vitro transfer of phosphate to the heptose moiety of the core. European Journal of Biochemistry II, 24I-248.

MüHLRADT, P. F. (197I). Biosynthesis of Salmonella lipopolysaccharide. Studies on the transfer of glucose, galactose and phosphate to the core in a cell-free system. European Journal of Biochemistry $\mathbf{1 8}, 20-27$.

Muller-Felter, S. \& Ebel, J. P. (1962). Séparation des acides ribonucléiques et des polyphosphates inorganiques. II. Mise au point d'une technique de séparation par adsorption différentielle sur charbon. Bulletin de la Société de Chimie Biologique 44, II 15 -I I 84.

Munoz, E., Nachbar, M. S., Schor, M. T. \& Salton, M. R. J. (I968). Adenosinetriphosphatase of Micrococcus lysodeikticus: selective release and relationship to membrane structure. Biochemical and Biophysical Research Communications 32, 539-546.

Ö̈BRG, B. \& PHILIPSON, L. (1967). Gel filtration of nucleic acids on sphere-condensed agarose. Archives of Biochemistry and Biophysics II9, 504-509.

SaUer, H. W., BabCock, K. L. \& Rusch, H. P. (1969). High molecular weight phosphorus compound in nucleic acid extracts of the slime mould Physarum polycephalum. Journal of Bacteriology 99, 650-654.

ThiLo, E. (1959). Die kondensierten Phosphate. Naturwissenschaften Ir, 367-373.

WANG, D. \& MANCINI, D. (1966). Studies on ribonucleic acid polyphosphate in plants. Biochimica et biophysica acta 129, 23 I-239. 